\title{
Плоскоклетъчен карцином на средното ухо с демонстрация на един случай
}

\author{
Сп. Тодоров \\ Катедра по УНГ-болести, \\ УМБАЛ „Царица Йоанна - ИСУЛ“ ЕАД - София
}

\begin{abstract}
The author is reviewing a clinical case of a patient with chronic otitis - epithimpanitis with cholesteatom with following malignisation two years after the surgical treatment.
\end{abstract}

\section{Резюме}

Авторът разглежда клиничен случай на болен с хроничен отит - епитимпанит с холестеатом с последваща малигнизация две години след оперативното лечение.
$\mathrm{K}$ арциномите на средното ухо са редки тумори и диагнозата им се поставя обикновено късно (1). Хистологично се касае най-често за плоскоклетъчен карцином (62.8\%), следван от аденокарцином (18.2) и други видове карциноми (2). По правило се засяга само едното ухо, но има съобщения и за двустранен карцином на средното ухо (3). Счита се, че хроничният отит е главен предразполагащ фактор за появата на карцинома на средното ухо (4).

За малигнена дегенерация трябва да се мисли, когато е налице упорито гноетечение от ухото, резистентно на приложеното консервативно лечение; когато има рецидивиращи гранулации; когато е налице оталгия. В по-късните стадии болката се усилва, появява се парализа на лицевия нерв и/или внезапна глухота (5).

Диагнозата се поставя чрез биопсия, а разпространението на тумора се уточнява с компютьрна томография на темпоралната кост (6). Последната до голяма степен определя стадия на тумора (TNM) и избора на лечение. Най-добри резултати засега има от оперативното отстраняване на тумора, последвано от лъчелечение (7).

Прогнозата на заболяването е лоша, най-вече поради късното диагностициране на тумора, довело до обхващане на важни мозъчни структури или метастази. Преживяване над 5 години се установява в $26 \%$ до $60 \%$ от болните (2).

\section{Клиничен случай}

Пациентката Ю.С.Н. на 42 г. бе приета за оперативно лечение в клиниката по УНГ-болести при УМБАЛ „Царица Йоанна - ИСУЛ“ с диагноза Otitis media suppurativa chronica sinistra - epitympanitis cum cholesteatoma. 
Om анамнезата: От ранна детска възраст е боледувала често от остро гнойно възпаление предимно на лявото ухо, протичащо с болка, гноетечение и фебрилитет. Лекувана е амбулаторно и в болнично заведение с антибиотици и симптоматични средства. Около пубертета, след поредното боледуване, пациентката забелязала, че секретьт, който изтича, има неприятна миризма. Оттогава многократно е лекувана с антибиотици и капки за уши. Заболяването протичало с периоди на екзацербации и ремисии. Неколкократно е предлагано оперативно лечение, което пациентката е отказвала. При поредното обостряне на заболяването болната бе хоспитализирана за оперативно лечение.

Cmamyc: Отоскопия синистра - широк външен слухов проход, зацапан с гноевиден секрет. На тъпанчевата мембрана се вижда епитимпанален дефект над задната малеоларна плика, от който изтича гноевиден ексудат с неприятна миризма. След промивка по Хартман се аспирираха холестеатомни люспи. Отоскопия декстра - атрофична мембрана с калциеви отлагания. Останалите ЛОР органи - б.о. Параклиничните изследвания бяха в рамките на референтните стойности. Аудиологичното изследване показа проводно намаление на слуха на лявото ухо около $40 \mathrm{~dB}$. На рентгенографията по Шулер - намалена пневматизация на клетките на proc. mastoideus, по-силно изразено вляво.

Проведе се оперативно лечение - Mastoidoaditoatticotomia sinistra. С ендаурален достъп се отвориха последователно антрумът, клетките на proc. mastoideus и адитус ад антрум, които бяха изпълнени с гранулационна тъкан и гноевиден ексудат, а голяма гранулация блокираше адитуса. B attic ce намери холестеатом и множество гранулации, слуховата верига беше прекъсната, като от наковалнята беше останало само тялото. Направи се широк „процеп“, свързващ клетките на proc. mastoideus и cavum tympany, като се запази задната стена на външния слухов проход. Изпрати се материал за патохистологично изследване, който показа наличие на „гранулационна тъкан“. Следоперативният период протече спокойно, без усложнения. При контролните прегледи, които се провеждаха на всеки три месеца през първата година и шест

\section{Литература:}

1. Saic DLJ, Djeric DR. Malignant tumors of the middle ear. Clin Otolaryngol 1991; 16: $87-89$

2. Gurgel LK, Karnell LH, Hansen MR. Middle ear cancer: a populationbased study. Laryngoscope 2009; 119 (10): $1913-7$.

3. Takano A, Takasaki K, Kumagami H, Higami Y, Kobajashi T. A case of bilateral middle-ear squamous cell carcinoma. J Laryngol Otol 2001; 115 (10): $815-18$.

4. Watkinson JC, Gase MN, Wilson JA. Stell and Maran's head and neck surgery. Butterworth-Heihemann, Oxford 2000; $431-440$. месеца през втората, ухото беше спокойно, без патологична секреция. В края на втората година след операцията, на поредния контролен преглед се установи разязвяване в ьгъла между задната и горната стена на външния слухов проход с размери около 3 мм в диаметьр и малки плоски гранулации. Патохистологичното изследване на взетия от там материал показа „високо към умерено диференциран вроговяващ плоскоклетьчен карцином“. Това наложи да се направи радикална трепанация, като суспектният участък отново се изпрати за хистологично изследване. Резултатът потвърди първоначалната диагноза „плоскоклетъчен карцином“.

Следоперативно пациентката беше обсьдена на клинико-радиологична среща, като се взе решение за последващ курс телегаматерапия. Той беше започнат един месец след операцията. След третата процедура от оперативната кухина започна да изтича бистър слузест ексудат, който се аспирираше периодично и продължи един месец след лъчетерапията.

На контролните прегледи една година след операцията оперативната кухина е спокойна, тапицирана с гладка лигавица, без данни за рецидив.

\section{Обсъждане}

Нашият случай потвърждава общоприетото мнение, че хроничният отит е най-важният предразполагащ фактор за поява на плоскоклетъчен карцином на средното ухо. Единственият белег за евентуална малигнена дегенерация при нашата болна беше появата на гранулации и разязвяване в горно-задната част на външния слухов проход след близо 2-годишен „светъл“ период след първата операция. Липсата на оталгия, засягане на лицевия нерв и други вътречерепни структури обясняваме със съвсем началния стадий на развитие на туморния процес. Диагнозата бе поставена след направената биопсия и бе потвърдена от хистологичното изследване на оперативния материал. Лечението включваше радикална мастоидектомия с последваща лъчетерапия. Болната е под наблюдение една година след операцията, през което време няма данни за рецидив и метастази.

5. Lewis JS. Squamous carcinoma of the ear. Arch Otolaryngol 1973; 97 : $41-42$.

6. Olsen KD, DeSanto LW, Forbes GS. Radiographic assessment of squamous cell carcinoma of the temporal bone. Laryngoscope 1983; 93 : $1162-67$.

7. Schwager K, Pfreunder L, Hoppe F, Baier G, Baier WJ. Carcinoma of the external ear canal and middle ear as interdisciplinary challenge for ear surgery and radiotherapy. Laryngorhinootology 2001; 80: 196-202. 